\title{
Structure of the Community of Dominant Fish Species Associated to Soft-Bottoms in the Lagoon of La Paz, B.C.S., México
}

\author{
Bruma R. Castillo-Rosas ${ }^{1}$, Emelio Barjau-González ${ }^{*}{ }^{\circledR}$, Juan Manuel López-Vivas ${ }^{1}$ (D), \\ Abril Karim Romo-Piñeda1 (10, Eleonora Romero-Vadillo1, Jose Ángel Armenta-Quintana² (1) \\ ${ }^{1}$ Departamento Académico de Ciencias Marinas y Costeras, Universidad Autónoma de Baja California Sur, \\ La Paz, México \\ ${ }^{2}$ Departamento Académico de Ciencia Animal y Conservación del Hábitat, Universidad Autónoma de Baja California Sur, \\ La Paz, México \\ Email: rosasr818@gmail.com, *ebarjau@uabcs.mx, jmlopez@uabcs.mx, \\ Akromo@uabcs.mx, eromero@uabcs.mx, jarmenta@uabcs.mx
}

How to cite this paper: Castillo-Rosas, B.R., Barjau-González, E., López-Vivas, J.M., Romo-Piñeda, A.K., Romero-Vadillo, E. and Armenta-Quintana, J.Á. (2020) Structure of the Community of Dominant Fish Species Associated to Soft-Bottoms in the Lagoon of La Paz, B.C.S., México. Open Journal of Marine Science, 10, 79-92. https://doi.org/10.4236/ojms.2020.103006

Received: April 21, 202

Accepted: May 12, 2020

Published: May 15, 2020

Copyright (C) 2020 by author(s) and Scientific Research Publishing Inc. This work is licensed under the Creative Commons Attribution International License (CC BY 4.0)

http://creativecommons.org/licenses/by/4.0/ (c) (i) Open Access

\begin{abstract}
The study of fish communities from coastal lagoons allows a better understanding of role of these organisms in these systems, and the effect of anthropogenic impact. The aim of the present study was to determine the community structure, in particular dominance of fish species associated to soft bottoms in the lagoon of La Paz. Six bimonthly samplings were carried out in seven localities from November 2016 to September 2017 and physicochemical parameters were recorded. Analysis of temperature showed differences between two marked seasons, warm and cold. Species richness showed differences between months and localities. Shannon-Weaver index and Pielou's evenness showed significant differences only between months. Simpson's index suggests a high diversity. According to the BVI, 15 species from the families Haemulidae, Sciaenidae and Gerreidae, were the most biologically important. Zoogeographic affinity analysis showed that $58 \%$ of the species prefer the Province of Cortez. Dominant species recorded in this study play a key role in soft-bottom systems like the lagoon of La Paz.
\end{abstract}

\section{Keywords}

Coastal Lagoon, Lagoon of La Paz, Diversity, Dominance

\section{Introduction}

México is a country with high biodiversity, including a high diversity of ich- 
thyofauna. Coastal areas in México with $11,000 \mathrm{~km}^{2}$, are characterized by a high number of coastal lagoons and estuaries, which are used by its diverse fish communities, especially the ones associated to soft bottoms, a characteristic feature of this type of lagoons. In addition, these lagoons play a key role in the reproductive cycles of many marine species and are also used for commercial fishing [1].

Coastal lagoons and estuaries are physically unstable areas that typically show spatial and temporal variations of water temperature, salinity, dissolved oxygen and turbidity [2]. This environmental complexity favours the ichthyofauna present there, which is usually characterized by juvenile organisms that use these coastal systems as feeding and breeding grounds. However, only a few species use these lagoons during their full life cycle, while many others use them during a specific part of their life cycle [3].

In addition, characterization of these soft-bottom systems is important because of their ecological features related to habitat heterogeneity, which favours a high biological diversity and primary productivity [4].

The lagoon of La Paz which is a coastal lagoon is characterized by its bathymetry, physicochemical variables, predominant sandy substrate on the north, and a combination of mud and sand on the south [5]. These features are important from an economic and ecological perspective because of the many ecosystem services that are carried out in the lagoon since the construction of docks and hotels on the its coast. In addition, sediment removal has been carried out to facilitate the traffic of a variety of vessels such as sailboats and yachts. These activities could be considered as modification of the habitat and could possibly affect key areas inhabited by fish communities. Therefore, the aim of this study was to determine the composition of the soft-bottom fish community of the coastal lagoon of La Paz throughout different seasons and localities.

\section{Methods}

\section{Studyarea}

The coastal lagoon of La Paz is located south of La Paz Bay (Figure 1), in the state of Baja California Sur, between the parallels $24^{\circ} 11$ and $24^{\circ} 06^{\prime}$, and between meridians $110^{\circ} 19^{\prime}$ and $110^{\circ} 25^{\prime}$. It is separated from La Paz Bay by a sand barrier known as "El Mogote" which has a length of $11 \mathrm{~km}$, with $2.7 \mathrm{~km}$ on the widest part [6].

Six samplings were carried out in seven localities (Table 1) every two months from November 2016 to September 2017, performing a total of 42 replicates. To collect fish species associated to soft bottoms, an experimental trawl net with a length of $9.5 \mathrm{~m}$, a vertical opening of $4.5 \mathrm{~m}$, a mesh size of $4.44 \mathrm{~cm}$ (1.75 inches), and metal doors of $95 \times 50 \mathrm{~cm}$, was used. The trawl speed was $3.5 \mathrm{~km} / \mathrm{h}$, sweeps lasted 20 minutes at an average depth of $5 \mathrm{~m}$. A 22 feet boat with a 75 HP four stroke outboard motor was used as a trawler.

Physicochemical variables such as water temperature $\left({ }^{\circ} \mathrm{C}\right)$, dissolved oxygen 


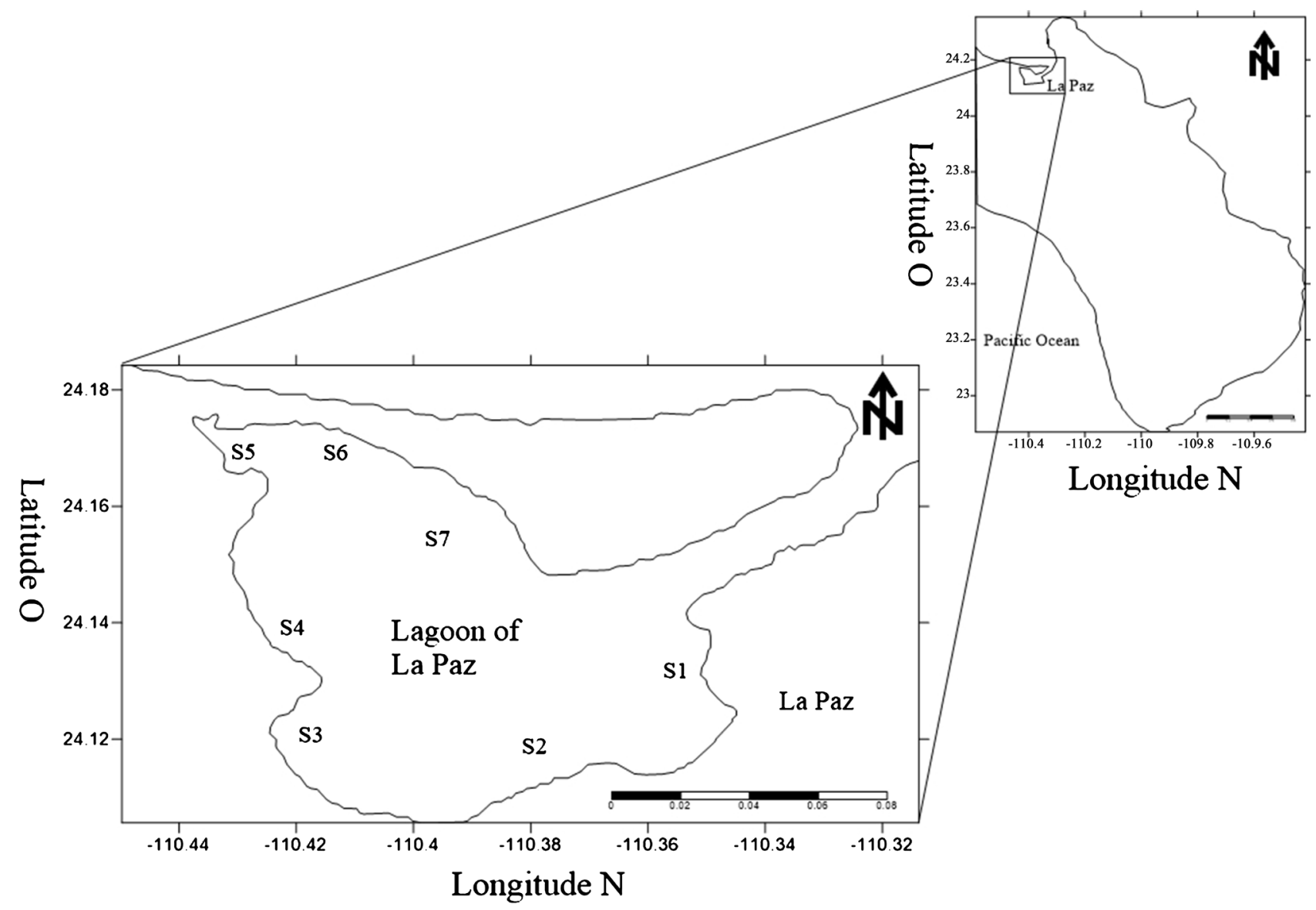

Figure 1. Geographic location of the study area (lagoon of La Paz, B.C.S.) and sampling sites. Grand Plaza (S1), Aeropuerto (S2), Aripez (S3), Cibnor (S4), Zacatecas (S5), Las Palmas (S6), Yate Hundido (S7) [32].

Table 1. Coordinates of the sampling sites in the lagoon of La Paz, B.C.S.

\begin{tabular}{ccc}
\hline Sampling sites & North & West \\
\hline S1 Grand Plaza & 2407.816 & 11021.480 \\
S2 Aeropuerto & 2407.264 & 11023.354 \\
S3 Aripez & 2407.243 & 11025.081 \\
S4 Cibnor & 2408.368 & 11024.859 \\
S5 Zacatecas & 2410.152 & 11025.627 \\
S6 Las Palmas & 2409.697 & 11024.338 \\
S7 Yate Hundido & 2408.851 & 11023.779 \\
\hline
\end{tabular}

and salinity (UPS) were recorded at each locality using a YSI 2030 Pro multiparameter instrument, at an average depth of $5 \mathrm{~m}$ (determined using a Secchi disk), at the same time of day during each sampling.

After collection, all fish specimens were analyzed in the fish ecology laboratory at the Autonomous University of Baja California Sur (UABCS). Morphometric measurements were carried out and weight was determined using a digital scale Ohaus Explorer Pro. Species identification was carried out using specia- 
lized literature. All fish specimens were preserved using $10 \%$ formaldehyde followed by $70 \%$ ethanol.

The following taxonomic indices were calculated using the software PRIMER 7 V 7.0.13 \& PERMANOVA+ 1 and statistical analysis were performed using STATISTICA version 12:

- Species richness index (SRI) (Margalef, 1977) can be used to determine change on species numbers depending on sample size.

$$
D=(S-1) / \ln N
$$

where: $D=$ species richness, $S=$ species number and $N=$ number of individuals.

- Shannon and Weaver Index $(H)$ is commonly used when samples are obtained using nets, traps or transects, which make similar studies in coastal lagoons comparable. This index shows the heterogeneity of a community using two measures: number of species and relative abundance [6].

$$
H^{\prime}=-\sum(p i)(\ln p i)
$$

where: $H^{\prime}=$ Shannon and Weaver index, $\ln p i=$ natural logarithm of the total of the sample.

- Pielou's evenness $(J)$ is calculated based on Shannon and Weaver index $(H)$. It is a component of diversity and an indirect measure of relative abundance. Uses values from 0 to 1 . Values closer to 1 indicate evenness, while values closer to 0 indicate dominance from a species.

$$
J^{\prime}=H^{\prime} / \ln (S)
$$

where: $J^{\prime}=$ Evenness, $H^{\prime}=$ Shannon and Weaver index and $S=$ number of species.

- Simpon's diversity index $\left(\mathrm{si}_{\mathrm{D}}\right)$ shows the probability of finding two individuals from different species in two successive random "samplings" without "replication". This index gives more weight to abundant species underestimating rare species, with values that range from 0 (low diversity) to 1 [ $1-$ $1 / S]$.

$$
S i_{D}=1-\sum_{i=1}^{S} P i^{2}=1-s i_{D}
$$

where: $S=$ total number of species, $p i=$ abundance of the $i$ th species, $n i=$ number of individuals of species I, $N=$ total number of individuals of all species from the community, $s i_{D}=$ number of "finite" communities.

- Species dominance calculation requires a hierarquisation of a community based on abundance and frequency of appearance of its species. Biological Value Index (BVI) [7] was used for this, which assigns a numerical value to a species abundance, based on the importance of the species in the community:

$$
\text { B.V.I. }=\sum \text { puijJi }=0
$$

where: $p u i j=$ al nivel de punto de las species $i$ in the sample $j$.

The zoogeographic affinity of the fish species was determined based on pre- 
vious literature [3] [8] [9] [10] [11] [12]. The following provinces were considered:

- Californian province: species with distribution on temperate-warm zone, ranging from Magdalena Bay to northern California, USA.

- Mexican province: species with a distribution from Magdalena Bay to The Isthmus of Tehuantepec, México.

- Province of Cortez includes species from the Gulf of California, with Cabo San Lucas as the southern limit and Mazatlán on the East.

- Panamic province: species distributed in the sub-tropical and tropical zone (from Magdalena Bay to Cabo Blanco, Perú).

- Eastern Pacific: widely distributed species, mainly from California to Perú.

\section{Results}

\section{Environmental variables}

Temperature was not significantly different between sampling localities ( $\mathrm{p}=$ $0.9675)$. Lowest temperature $\left(23.28^{\circ} \mathrm{C}\right)$ was recorded in the Zacatecas locality, whilst the highest was recorded at Gran Plaza $\left(25.42^{\circ} \mathrm{C}\right)$. Temporal comparison showed significant differences $(\mathrm{p}<0.05)$ (Table 2).

Salinity was not significantly different between sampling localities $(\mathrm{p}>0.05)$. Lowest salinity was recorded at Gran Plaza (31.78 UPS), whilst the highest value was recorded at Cibnor 33.68 UPS). In addition, comparison between months did not show significant differences $(\mathrm{p}=0.6343)$. The highest salinity value was

Table 2. Summary of the environmental variables and ecological indices measured at each sampling site and month.

\begin{tabular}{ccccccc}
\hline $\begin{array}{c}\text { Sampling } \\
\text { sites/Months }\end{array}$ & $\begin{array}{c}\text { Temperature } \\
\left({ }^{\circ} \mathrm{C}\right)\end{array}$ & Salinity (UPS) & $\begin{array}{c}\text { Species } \\
\text { richness (SRI) }\end{array}$ & $\mathbf{H}^{\prime}$ & $\mathrm{J}^{\prime}$ & $\mathbf{s i}_{\mathrm{D}}$ \\
\hline S1 & 25.42 & 31.78 & 1.26 & 0.93 & 0.64 & 0.59 \\
S2 & 23.70 & 33.60 & 1.13 & 0.93 & 0.73 & 0.60 \\
S3 & 24.17 & 33.32 & 2.55 & 1.65 & 0.91 & 0.87 \\
S4 & 24.07 & 33.68 & 2.30 & 1.72 & 0.92 & 0.86 \\
S5 & 23.28 & 32.02 & 2.97 & 2.00 & 0.91 & 0.88 \\
S6 & 24.23 & 33.33 & 1.31 & 0.99 & 0.73 & 0.62 \\
S7 & 24.18 & 33.67 & 2.03 & 2.00 & 0.73 & 0.66 \\
August & 28.17 & 33.30 & 2.58 & 1.79 & 0.91 & 0.89 \\
October & 26.74 & 33.97 & 1.04 & 1.98 & 0.91 & 0.88 \\
December & 22.71 & 33.19 & 1.52 & 1.91 & 0.90 & 0.88 \\
February & 21.43 & 32.77 & 2.23 & 2.10 & 0.91 & 0.88 \\
April & 23.04 & 31.90 & 3.14 & 1.90 & 0.90 & 0.88 \\
June & 22.80 & 33.21 & 1.11 & 2.00 & 0.91 & 0.89 \\
\hline
\end{tabular}

${ }^{*}$ Species richness index (SRI), Shannon and Weaver Index $\left(\mathrm{H}^{\prime}\right)$, Pielou's evenness $\left(\mathrm{J}^{\prime}\right)$, Simpon's diversity index $\left(\mathrm{si}_{\mathrm{D}}\right)$. 
recorded in October (33.97 UPS), whilst the lowest value was recorded in April (31.90 UPS) (Table 2).

\section{Species richness}

Temporal analysis showed significant differences between months $(\mathrm{p}<0.05)$. Highest value of species richness was recorded in April $(d=3.1)$, while the lowest value was recorded in October (1) (Figure 2). In addition, spatial analysis also showed significant differences between localities $(\mathrm{p}=0.043)$. The highest value was recorded in Zacatecas $(d=2.9)$, located south of the lagoon, while the lowest value was recorded in Aeropuerto $(\mathrm{d}=1.1)$, followed by Grand Plaza $(\mathrm{d}=$ 1.2) (Table 2).

\section{Shannon and Weaver Index}

Temporal analysis of this index showed significant differences between months $(\mathrm{p}<0.05)$. These values show a higher diversity during April $\left(H^{\prime}=2.09\right)$ and lower diversity during October $\left(H^{\prime}=1.78\right)$. Moreover, spatial analysis of this index showed no significant differences between localities $(\mathrm{p}=0.054)$. The highest value of diversity was recorded in Zacatecas $\left(H^{\prime}=1.9\right)$, while the lowest value was recorded in Grand Plaza and Aeropuerto $\left(H^{\prime}=0.93\right)$ (Table 2).

\section{Evenness}

Temporal analysis of evenness showed significant differences $(\mathrm{p}=0.015)$. Lowest values were recorded in October $\left(J^{\prime}=0.6\right)$ and December $\left(J^{\prime}=0.5\right)$, while the rest of the months showed little variation, ranging from $J^{\prime}=0.88$ to 0.93 . Spatial analysis showed no significant differences $(\mathrm{p}=0.054)$, with Aripez, Cibnor and Zacatecas recording the highest value $\left(J^{\prime}=0.91\right)$, while the lowest evenness was recorded in Grand Plaza $\left(J^{\prime}=0.63\right)$ (Figure 2).

Simpson index

Temporal analysis showed significant differences between months $(p=0.0176)$

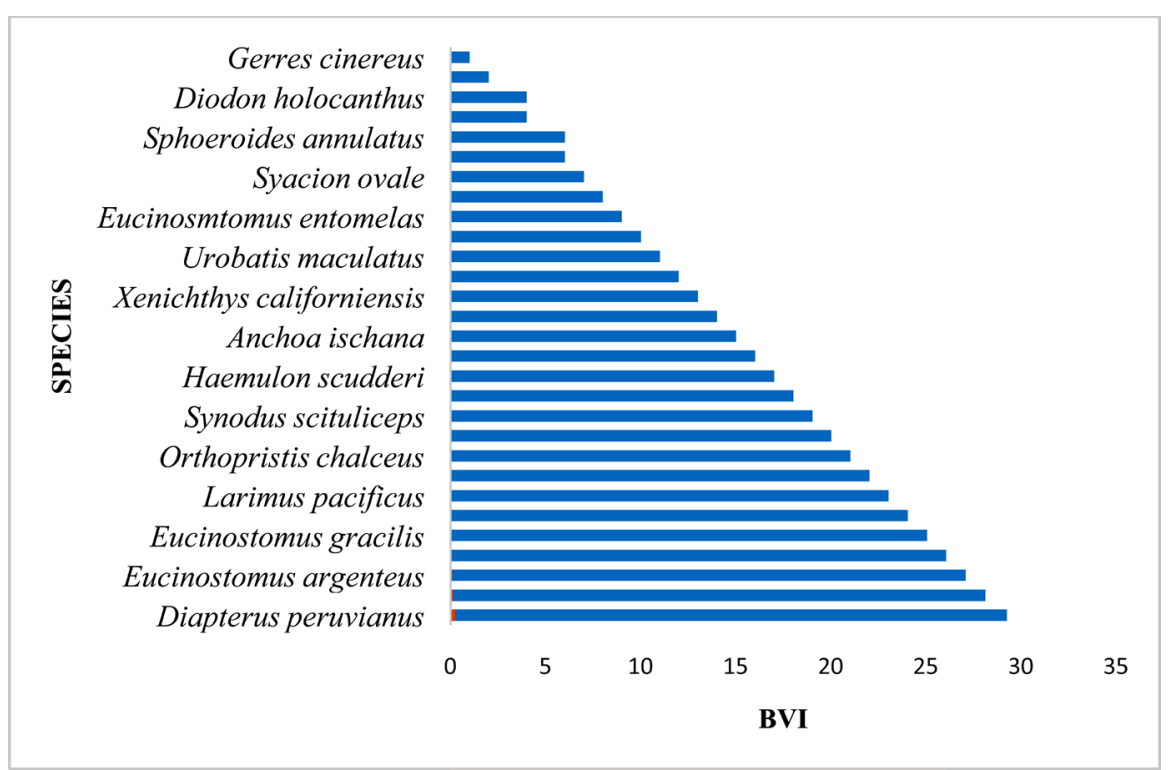

Figure 2. Temporal dominance of the most representative species collected in the lagoon of La Paz according to Biological Value Index (BVI). 
Lowest diversity value was $s i_{D}=0.49$, recorded in December, and the highest value was $s i_{D}=0.89$, recorded in August. Spatial analysis did not show significant differences $(\mathrm{p}=0.252)$. Lowest diversity value was recorded in Grand Plaza $\left(s i_{D}=\right.$ $0.58)$, while the highest value was recorded in Zacatecas $\left(s i_{D}=0.87\right)$ (Table 2$)$.

Dominance ( $B V I)$

A total of 73 species were collected. Fifteen species showed the highest values of BVI: Diapterus peruvianus, Paralabrax maculatofasciatus, Eucinostomus argenteus, Haemulon sexfasciatum, Eucinostomus gracilis, Eucinostomus currani, Larimus pacificus, Achirus. mazatlanus, Orthopristis chalceus, Diplectrum pacificum, Synodus scituliceps, Urotrygon reticulata, Haemulon scudderi, Euguerres. axillaris, Anchoa. ischana, Stellifer sp., Xenichthys californiensis, Euguerres lineatus, Urobatis maculatus, Calamus brachysomus, Eucisnostomus entomelas, Anisotremus interruptus, Syacion ovale, Orthopristis reddingi, Sphoeroides annulatus, Bardiella icistia, Diodon holocanthus, Haemulopsis leuciscus and Guerres cinereus (Table 2).

\section{Zoogeographic affinity}

The zoogeographic affinity analysis showed that $58 \%$ of the fish species recorded are from the Province of Cortez, 24\% from Mexican province, 17\% from Californian province, and 1\% from Panamic province (Figure 3).

\section{Discussion}

\section{Environmental variables}

The lagoon of La Paz showed spatial and temporal variation of temperature. Temporal analysis showed an increase from August to October, with an average temperature of $27.45^{\circ} \mathrm{C}$, and a decrease from December to June, with an average temperature of $22.49^{\circ} \mathrm{C}$. These findings are similar to what was previously reported by Cervantes-Duarte et al. [13], who also recorded the temperature inside the lagoon, using a Mini CTD InterOcean logger, and found a minimum temperature in January $\left(20^{\circ} \mathrm{C}\right)$ and a maximum $\left(30^{\circ} \mathrm{C}\right)$ during August, with a clear decrease from $30^{\circ} \mathrm{C}$ to $21^{\circ} \mathrm{C}$, from September to December. In addition, Barjau-González et al. [14] carried out a study in La Paz Bay (adjacent to this lagoon), recorded the temperature with a YSI Model 55 multiparameter instrument and found similar values around the same months, with a temperature of $23^{\circ} \mathrm{C}$

Mexican Province (PM) 58\%

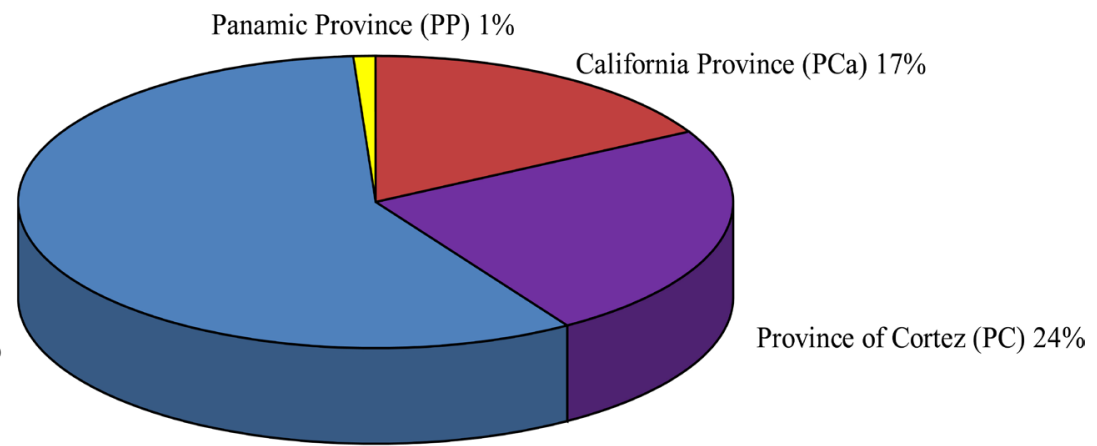

Figure 3. Zoogeographic affinity of fish species collected in the lagoon of La Paz. 
from April to June and a temperature of $27^{\circ} \mathrm{C}$ from August to December. Another study carried out in San Ignacio lagoon by Barjau-González [3], where temperature was recorded using a similar instrument (YSI Model 33) showed slightly lower values around $25^{\circ} \mathrm{C}$ during the summer months, but a lower temperature $\left(11.2^{\circ} \mathrm{C}\right)$ during the winter months.

Malpica-Maury [15] mentioned that temporal variation of temperature in the lagoon of La Paz can be influence by sedimentation, which is strongly influenced by wind and tide patterns that change the dynamic of the substrate. Similar to what was found in the present study. In addition, González-Acosta [16] mentioned that the arid climate, characterized by low precipitation, alongside wind patterns, strong winds from November to May coming from the Northwest, that switch to calmer winds during Spring and Summer.

Spatial analysis of temperature showed no significant differences, however, there was a little increment in the sampling sites located far away from the entrance of the lagoon. This variation is probably a result from the daily movement of different bodies of water, which was demonstrated in a study by Sánchez-Velasco et al. [17] in La Paz Bay, where current loggers were deployed on the entrance of bay. The one deployed on the West coast of the mouth found a continuous entrance of water from the Gulf of California towards the South-Southeast of the Bay, and the one deployed on the East coast found a continuous exit of water from the Bay to the Gulf of California towards the Northeast. A study by Barjau-González [3] in San Ignacio lagoon found spatial differences of temperature, decreasing as the depth increased. In addition, Muñoz-Félix [18] who carried out a study in the same lagoon, found no significant differences, however, a similar pattern was found in the sites located far away from the entrance of the lagoon, with an increase of temperature as the distance from the entrance increased.

Temporal and spatial analysis of the temperature did not show significant differences. The lowest value (23.6 UPS) was recorded in April in sites located further away from the entrance of the lagoon. According to González-Acosta [16], the lagoon of La Paz has a daily evaporation of 33\%, and up to 55\% during spring tide. In addition, this lagoon is considered as hypersaline because there is low input of freshwater and a high degree of evaporation, therefore, finding high values of salinity. Similar results were reported by Félix-Muñoz [18] in San Ignacio lagoon, who recorded the lowest value of 31.1 UPS, and argued that high values can be attributed to bathymetry (shallow areas), upwelling zone, currents, amount of sunlight and evaporation. Similar to a study by Acevedo-Cervantes [19] in Ojo de Liebre lagoon, who also argued that oceanographic events such as upwellings and currents have a high influence in salinity and other environmental variables in these types of lagoons.

\section{Species richness}

Species richness comparison between months showed a seasonal pattern. There was a decreased on the number of species during the fall and winter 
months (from October to February), and an increment during the months of April-August (spring and summer). This pattern of variation between seasons was also found in studies by González-Acosta [16] and Balart et al. [20], where number of species increased during the warmer months and decreased during the colder months. In addition, Malpica-Maury [15] found the highest number of species during summer, belonging to the families Gerreidae and Haemulidae, while the lowest number of species was found during winter, belonging mainly to the family Gerreidae. According to these studies and our results, we can infer that there are two seasons of high and low diversity, which changes because species move in and out of the lagoon following favourable environmental conditions.

Species richness also showed significant differences between localities. As previously mentioned, highest value was recorded in Zacatecas (located south of the lagoon), while the lowest value was recorded in Aeropuerto, this is probably because of a higher complexity of the substrate from that area, compared to other localities. Barjau-González [21] found similar results in La Paz Bay, and Rodríguez-Romero et al. [22] in a nearby Bay, with no significant differences. However, Muñoz-Félix [18] found spatial differences of species richness in San Ignacio lagoon, possibly due to environmental differences in this lagoon.

Shannon-Weaver index

Diversity analysis showed temporal differences, with the highest value recorded during April, and the lowest value in October. However, the diversity value is considered low, similar to that one found by Spellerberg and Fedor [23], who mentioned that values lower than three are considered as low diversity.

Our results are similar to what was reported by Barjau-González [14] in a study carried out in La Paz Bay, which found no significant differences of this index. In addition, a similar study in San Ignacio lagoon [18] found no significant temporal and spatial differences, and distribution of fish species.

Malpica-Maury [15] found a high diversity during winter and low Barjau-González [3] who carried out a study in the same area, found a seasonal pattern in the composition diversity during the summer. However, Rodríguez-Romero et al. [22] found a higher diversity during April and lower during October in a study carried out in Rancho Bueno lagoon, near Magdalena Bay. In addition, Acevedo-Cervantes [19] carried out a study in Ojo de Liebre lagoon using different fishing techniques: with gillnet, diversity was higher during July and lower during September. However, using dragnet, the highest value of diversity was recorded in September, and the lowest was recorded in July.

Regarding the spatial analysis, there were no significant differences of diversity between localities, with the highest value recorded in Zacatecas, located on the southern region of the lagoon, por lo que se puede inferir una distribución espacial uniforme, influyendo directamente la diversidad de la zona, en la que se pueden encontrar especies residentes y transitorias dependiendo del substrato y sitio de la laguna. In addition, Rodríguez-Romero et al. [22] found lower diversity 
values on the northern localities, while the highest values were recorded in the southern localities. Therefore, we can infer that the south of the lagoon attracts more animals, perhaps because of more favourable environmental conditions.

Evenness

Regarding temporal analysis of evenness, lower values were recorded during October and December, contrary to what Malpica-Maury [15] found in the same area, where the highest values were recorded during winter, while the lowest values were recorded during the summer, which is probably due to the dominance of the species found in the area. In addition, Barjau-González [21] also analysed this index, finding no significant differences, recording the highest value of evenness during June, and the lowest value during August.

Spatial analysis in this study found no differences, with the lower value recorded in Gran Plaza. Contrary to a study carried out in La Paz Bay by Barjau-González [21], who found differences between localities, probably due to distribution and dominance of the species. Similar studies by Barjau-González [3] and Muñoz-Félix [18], carried out in San Ignacio lagoon, found lower values of evenness.

\section{Simpson index}

Temporal analysis of this index showed significant differences between months, probably due to the productivity cycle of the area during the different months, where abundance increases but dominance decreases and vice versa. Martínez-Guevara [24] considers that a factor that could explain these differences of diversity of fish communities are the fishing techniques used to collect the animals. On the other hand, Sarur-Zanatta et al. [25] showed that rocky and muddy areas present high diversity values compared to sandy areas.

Spatial analysis of this index showed no significant differences, inferring that variation of diversity is due to species preferences for certain substrates with a high number of refugia associated with those. Therefore, loose substrates, such as gravel, may have a higher diversity than a homogeneous habitat [25].

Dominance ( $B V I)$

This index considers that a dominant species should have a balance between abundance and frequency of appearance [26]. According to BVI analysis, dominant families recorded in this study: Gerreidae, Haemulidae, Labrisomidae, Lutjanidae, Paralichthyidae, Sciaenidae, Serranidae and Urotrygonidae. Following the same criteria, 16 species were classified as dominant, showing high values of BVI: D. peruvianus, $P$. maculatofasciatus, E. argenteus, $H$. sexfasciatum, and $E$. gracilis. Contrasting results were obtained by results González-Acosta [16], who found that the most dominant species in a mangrove area close to our study area was $E$. currani, with a BVI value of $21.9 \%$. However, this species belongs to one of the dominant families in our study. In addition, dominance showed higher homogeneity on species captured using gillnet, such as D. peruvianus, $M$. curema, E. currani and E. estomelas, probably because this fishing technique aims to capture high number of animals. In addition, the temporal and spatial variation 
of the temperature, alongside movement of resident and transit species, could influence the difference of dominance in nearby areas.

Balart et al. [20] mentions that dominance can alternate between species because depends on abundance and the following patterns: 1) species that follow the same variation as temperature, similar to what was found in this study, where higher values of abundance were recorded in the warmer months and lower values in the colder months; 2 ) species that follow an opposite pattern; and 3) when there is more than one peak of abundance in a year, resulting in temporal and spatial analysis.

Similar studies in adjacent areas showed similar results where dominant species have a high frequency of appearances [3] [14] [15] [18] [27] [28].

BVI shows percentages, which could be consider as inconsistent because it does not show the exact value of abundance. However, this is an abstract index that gets specific information about the community [26], therefore, it shows the information needed for this study.

\section{Zoogeographic affinity}

Regarding zoogeographic affinity, Aguirre et al. [29] carried out a study in La Paz Bay, where most of the fish ensembles belong to three provinces: Panamic province from [30], Mexican province [7] and Sinus-Californica province [31], which are considered transition zones with similar characteristics as the provinces from the present study.

Balart et al. [20] compared the distribution of fish collected in La Paz Bay and suggested two main aspects of the area that can have an effect on diversity and abundance; 1) increase of anthropogenic activities in the area, and 2) decrease of favourable habitats due to pollution (sewer water discharge). However, according to our results, temperature was a probable factor affecting the spatial distribution of the fish communities inside the lagoon.

\section{Conclusion}

The pattern of variation of the environmental variables recorded in this study corresponds to a well-defined seasonal cycle, with a warm season in the summer and a cold season in the winter months. According to the BVI, the dominant families were Haemulidae, Sciaenidae, Gerreidae, Paralichthyidae, Urotrygonidae and Serranidae, and its species play a key role in the soft-bottom systems they are associated with.

\section{Authors' Contributions}

BRCR co-wrote the manuscript with EBG. EBG carried out fish collection and ID and analyzed data. AKRP, ERV, JMLV and JAAQ contributed to revisions. All authors read and approved the final manuscript. Likewise, they declare no conflict of interest.

\section{Acknowledgements}

Authors would like to thank Autonomous University of Baja California Sur 
(UABCS) for allowing the use of its facilities (Fish Ecology Laboratory), and M.Sc. Myrna Barjau Pérez Milicua for the English editing of the manuscript.

\section{Conflicts of Interest}

The authors declare no conflicts of interest regarding the publication of this paper.

\section{References}

[1] Galván-Villa, C.M., Arreola-Robles, J.L., Ríos-Jara, E. and Rodríguez-Zaragoza, F.A. (2010) Ensamblajes de peces arrecifales y su relación con el hábitat bentónico de la Isla Isabel, Nayarit, México. Revista de biología marina y oceanografía, 45, 311-324. https://doi.org/10.4067/S0718-19572010000200013

[2] Palomino, B.A., Romero, J.M., Ibarra, L.E.R. and Sansón, G.G. (1996) Íctiofauna demersal de fondos blandos de la plataforma continental de Jalisco y Colima, México, en la primavera de 1995. Ciencias Marinas, 22, 469-481. https://doi.org/10.7773/cm.v22i4.1216

[3] Barjau-González, E. (2003) Estructura de la íctiofauna asociada a fondos blandos en laguna san Ignacio, baja california sur, México (maestría). Instituto politécnico nacional.

[4] Padilla-Serrato, J., López-Martínez, J., Rodríguez-Romero, J., Acevedo-Cervante, A., Galván-Magaña, F. and Lluch-Cota, D. (2017) Changes in Fish Community Structures in a Coastal Lagoon in the Gulf of California, México. Revista de Biología Marina y Oceanografía, 52, 567-579. https://doi.org/10.4067/S0718-19572017000300013

[5] Reyes-Salinas, A., Cervantes-Duarte, R., Morales-Pérez, R.A. and Valdez-Holguín, J.E. (2003) Variabilidad estacional de la productividad primaria y su relación con la estratificación vertical en la Bahía de La Paz, BCS. Hidrobiológica, 13, 103-110.

[6] Cervantes-Duarte, R. and Guerrero-Godínez, R. (1987) Variación espacio-temporal de nutrientes de la Ensenada de La Paz, B.C.S., México. Anales del Instituto de Ciencias del Mar y Limnología, 27 p.

[7] Sanders, H.L. (1960) Benthic Studies in Buzzards Bay. II. The Structure of the Soft Bottom Community. Limnology Oceanograpy, 5, 138-153. https://doi.org/10.4319/lo.1960.5.2.0138

[8] Briggs, J.C. (1974) Marine Zoogeography. McGraw-Hill Book Company, New York, 475 p. https://doi.org/10.2307/1442613

[9] Hubbs, C.L. (1960) The Marine Vertebrates of the Outer Coast. Symposium: The Biogeography of the Baja California and Adjacent Seas. Systematic Zoology, 9 , 134-147. https://doi.org/10.2307/2411962

[10] Rosenblatt, R.H. (1967) The Zoogeographic Relationship of the Marine Shore Fishes of Tropical America. Studies of Tropical Oceanography Miami, 5, 579-592.

[11] Thomson, D.A., Findley, L.T. and Kerstitch, A.N. (2000) Reef Fishes of the Sea of Cortez. Texas Press, College Station, TX, 375 p.

[12] De la Cruz-Agüero, J. (2000) Origen y distribución de la íctiofauna de la Laguna de San Ignacio, Baja California Sur, México. CIENCIA ergo-sum, 7, 157-165.

[13] Cervantes-Duarte, R., Aguirre Bahena, F., Reyes Salinas, A. and Valdez Holguín, J.E. (2001) Caracterización hidrológica de una laguna costera de Baja California Sur, México. 
[14] Barjau-González, E., Rodríguez-Romero, J., Galván-Magaña, F. and Maldonado-García, M. (2016) Variación estacional de la diversidad taxonómica de los peces de arrecifes ro-cosos en el suroeste del Golfo de California. Revista de biología marina y oceanografía, 51, 11-19. https://doi.org/10.4067/S0718-19572016000100002

[15] Malpica-Maury, O.M. (1999) Ictiofauna de la Ensenada de La Paz, BCS, México (Doctoral dissertation, Instituto Politécnico Nacional. Centro Interdisciplinario de Ciencias Marinas).

[16] González Acosta, A.F. (1998) Ecología de la comunidad de peces asociada al manglar del Estero El Conchalito, Ensenada de La Paz, Baja California Sur, México. Doctoral Dissertation, Instituto Politécnico Nacional. Centro Interdisciplinario de Ciencias Marinas.

[17] Sánchez-VelascO, L., Jiménez-Rosenberg, S.P.A., Shirasago, B. and Obeso-Nieblas, M. (2004) Distribution and Abundance of Fish Larvae in Bahia De La Paz (Gulf of California) and Their Relation to Hydrographic Variability during Summer (1997-1998). Deep Sea Research Part II: Topical Studies in Oceanography, 51, 723-737. https://doi.org/10.1016/j.dsr2.2004.05.020

[18] Muñoz-Felix, F.A. (2017) Estructura de la comunidad de peces asociados a fondos blandos y su papel ecológico en la Laguna San Ignacio, BCS, México.

[19] Balart, E.F., Castro-Aguirre, J.L. and De Lachica-Bonilla, F. (1997) Análisis comparativo de las comunidades ícticas de fondos blandos y someros de la Bahía de La Paz, BCS. La Bahía de La Paz investigación y conservación, Universidad Autónoma de Baja California Sur, 177-188.

[20] Barjau-González, E. (2012) Estructura comunitaria y diversidad taxonómica de los peces en la Bahía de la Paz y la Isla San José, Golfo de California.

[21] Acevedo-Cervantes, A. (1997) Caracterización ecológica de la comunidad íctica de la Laguna Ojo de Liebre, BCS México. Doctoral Dissertation, Instituto Politécnico Nacional. Centro Interdisciplinario de Ciencias Marinas.

[22] Rodríguez-Romero, J., López-González, L.D.C., Galván-Magaña, F., Sán-chez-Gutiérrez, F.J., Inohuye-Rivera, R.B. and Pérez-Urbiola, J.C. (2011) Cambios estacio-nales de la comunidad de peces asociada a zonas de manglar en una laguna costera de Baja California Sur, México. Latin American Journal of Aquatic Research, 39, 250-260. https://doi.org/10.3856/vol39-issue2-fulltext-6

[23] Spellerberg, I.F. and Fedor, P.J. (2003) A Tribute to Claude Shannon (1916-2001) and a Plea for More Rigorous Use of Species Richness, Species Diversity and the 'Shan-Non-Wiener' Index. Global Ecology and Biogeography, 12, 177-179. https://doi.org/10.1046/j.1466-822X.2003.00015.x

[24] Martínez-Guevar, A.A. (2008) Análisis de la ictiodiversidad y patrones biogeográficos en los sistemas costeros de Baja California Sur.

[25] Sarur-Zanatta, J.C., Millán-Núñez, R., Gutiérrez-Sigala, C.A. and Small-Mattox-Sheahen, C.A. (1984) Variation and Similarity in Three Zones with-Different Type of Substrate in Laguna Ojo De Liebre, BCS, Mexico. Ciencias Marinas, 10, 169-179. https://doi.org/10.7773/cm.v10i2.436

[26] Loya-Salinas, D.H. and Escofet, A. (1990) Aportaciones al c5lculo del Indice de Valor Biol6gico (Sanders, 1960). Contriiution to the calculation of the Biological Value Index (Sanders, 1960). Ciencias Marinas, 10, 97-115. https://doi.org/10.7773/cm.v16i2.688

[27] De La Cruz-Agüero, J. and Cota Gómez, V.M. (1998) Íctiofauna de la laguna de San Ig-nacio, Baja California Sur, México: Nuevos registros y ampliaciones de ámbito. 
Ciencias Marinas, 24, 353-358. https://doi.org/10.7773/cm.v24i3.751

[28] Arreola-Robles, J.L. (1998) Diversidad de peces de arrecife en la región de La Paz, BCS, México. Doctoral Dissertation, Instituto Politécnico Nacional. Centro Interdiscipli-nario de Ciencias Marinas.

[29] Aguirre, J.C., Balart, E.F. and Martínez, J.A. (1995) Contribución al conocimento del ori-gen y distrubución de la ictiofauna del Golfo de California, México. Hidrobiológica, 5, 57-78.

[30] Ekman, S. (1953) Zoogeography of the Sea (Vol. 9). Sidgwick and Jackson, London. https://doi.org/10.2307/1439946

[31] Castro-Aguirre, J., González-Acosta, A. and de la Cruz-Agüero, J. (2005) Lista anotada de las especies ícticas anfipacíficas, de afinidad boreal, endémicas y anfipeninsulares del golfo de california, México. Anales de la Escuela Nacional de Ciencias Biológicas, México, 21, 85-106.

[32] Castillo-Rosas, B.R. (2019) Estructura de la comunidad de las especies de peces dominantes asociados a fondos blandos de la laguna costera de La Paz, B.C.S., México. Tesis-UABCS. $81 \mathrm{p}$. 